\title{
Traditional Rulership and Local Governance in South- South Nigeria
}

\author{
Kingdom E. Orji, PhD \\ Associate Professor Department of History \& Diplomatic Studies Ignatius Ajuru University of Education, \\ Rumuolumeni, Port Harcourt, Rivers State Nigeria.
}

\begin{abstract}
The evolution of political cultures in relation to the emergence of traditional rulership and local governance has engaged the attention of wary scholars on the Nigerian polity and the operation of nascent democracy. This paper navigates the critical variables responsible for the changing roles of traditional rulership and the metamorphosis under-gone by local government administration. British colonial incursion and the eventual subjugation of "subject people" dismantled primordial structures to the extent that in postindependent $21^{\text {st }}$ Century Nigeria, constitution no statutory reference was made to the role of traditional institutions. Ironically, the same colonial onslaught has witnessed transformation in local government administration from the Native Authorities, local government authority, district, local councils, development administration to the cabinet parliamentary system bereft of any significant impact on the livelihood of the governed. One of the quintessential objectives of local governance is grassroot development. The main thrust of this paper is how to reposition these institutions to fulfill their primary mandate by eliminating bottle necks such as the "Nigerian factor" which is a euphemism for ineptitude and endemic corruption.
\end{abstract}

Key words: traditional rulership, local governance, 'Nigerian factor', grassroot development.

\section{Introduction}

Issues bordering on traditional rulership and local government administration have occupied the center stage in the political history of Nigeria prior to the epochal amalgamation of 1914 and the eventual granting of independence from British hegemony in 1960. It is worthy of note that critical factors are responsible for the survival of traditional institution in $21^{\text {st }}$ Century Nigeria. It is common knowledge that within the pre-colonial milieu, traditional rulers held sway and welded maximum powers but during the colonial era this institution witnessed a metamorphosis that whittled its influence and this has depreciated even in neo-colonial and democratic dispensation.

The evolution of local government administration in Nigeria could be examined in four phases basically "the colonial native authorities in the fifties, the decline of these councils in the sixties and early seventies and the reforms introduced on a national scale in 1976 Orewa and Adewumi (1983: xi). The obvious fact remains that the primary goal of traditional rulership and local government revolves around grassroot development for the teeming masses domiciled in the rural areas. This paper intends to clarify some key concepts, trace the evolution of traditional institution and local government authority and also delineate their relevance in the democratic governance of the South-South zone and by extension the Nigerian nation in this $21^{\text {st }}$ Century.

\section{Explication of Concepts:}

The term 'traditional rulership' emanates from the root word 'tradition' which deals with the customs, beliefs, rites and mores of the indigenous population. In the words of Agbese (2004:1) 'the institution of traditional rulers is an enduring part of our heritage; it plays a critical role as the custodian of culture and traditions. Expectedly, our traditional rulers are closely linked with the grassroots, and so understand the problem of our people intimately. Fasehun (2010:103) opines that 'traditional rulers are the heads of their communities and they owe their legitimacy to customs and traditions. They are popularly chosen by the gods, represent them on earth and have religious sanctity. They are regarded as very powerful and custodians of spiritual activities. According to Roberts (2004:17) the proceedings of the Ibrahim Dasuki Committee on the Review of Local Government Administration in 1984 defines a traditional ruler as 'the person who by virtue of his ancestry occupies the throne or stool of an area and who has been appointed to it in accordance with the custom and tradition of the area and has suzerainty over the people of that area. Still in the same vein, Emordi and Osiki (2010:481) submit that 'the traditional institution is associated with the concept of divine kingship, which has a lot to do with ritual leadership and magico-social-political authority enhanced through elaborate celebrations and practices'. 
The local government authority is subsumed under the three-tier administrative frame work of the federal government of Nigeria. Its sole aim is to usher in the dividends of democracy at the door-step of the governed. Under the federal structure, the local government component occupies a strategic position not only for the actualization of stated objectives but also for the dissemination of critical information in the overall interest of the citizenry. But what does the local government represent?

The federal government guidelines for the 1976 Local Government Reforms (cited in Oborgu,2006:19) defines local government as " government at local level exercised through representative councils established by law to exercise powers within defined areas. These power should guarantee provision of service and to determine and implement projects so as to complement the activities of the state and federal governments in their areas, and to ensure, through devolution of these functions to these councils and through the active participation of the people and their traditional institutions, that local initiatives and response to local needs and conditions are maximized". Okara (2009:2) in his contribution, views local government administration as a mechanism contrivance to manage the matters concerning the inhabitants of a political locality by the local population directly or through representatives chosen from its midst and acting in accordance with duties and powers conferred on them by competent political authority, the central or state legislature.

The explanation offered by Assibong and Akpan (2006:106) on the status of a local government is very instructive. They unequivocally state that 'local government is not the same thing as local administration which is synonymous with the administration of local communities essentially by means of local agents appointed by and responsible to the central government, region or national. Local government on the other hand implies a system of territorial units with defined boundaries, a legal identity, an institutional structure and powers and duties laid down in general and specific status and a degree of financial autonomy. Awofeso, O. (2006:87) associates local government with a tool of decentralization in that it (i.e. decentralization) is the umbrella term embracing all forms of delegation of responsibilities and /or authority within and between organizations. In his view, Orluwene (2007:11) while acknowledging the grassroot dimension notes that a local government is a political administrative structure for governing at the sub-State or sub-Nationallevel. He further adds that not all political and administrative structure at the local level can qualify to be called local government local government involves the establishment or enthronement of Government which in a democratic structure must be freely formed by the people'

The South-South zone is a political creation of the Fourth Republic. Generally there are six geopolitical zones namely the North-East, North-West, North Central, South-East, South-West, and South-South zones. The South-South zone comprises six distinct states namely Akwa-Ibom, Bayelsa, Cross-River, Delta, Edo and Rivers. These six states by virtue of their geographical congruency share some common historical, cultural, and socio-economic traits such as traditions of origin, similar colonial experiences, marginilisation, etc. This zone accommodates various ethnic groups viz the Ijaw, the Urhobo, Itsikiri, Ogoni, Efik, Ikwere, Etche, AbuaOdual, Ekpeye, OgbahEgbema, Ndoni, Degema, Ibani, Ndokki, Ishan, Bini, Kwale, EpeAtissa, KaIbo,Ogbia etc. speaking diverse languages. According to Dike (1956) the indigenous settlers of thisZone took active part in the Trans-Atlantic Trade and the Legitimate Commerce that served as a forerunner to colonial subjugation.

\section{Traditional rulership in historical perspective}

In pre-colonial times, traditional rulers welded maximum powers and were seen as the custodian of the custom of the people. Some of them even doubled as priests. Adesoji (2010:417) observe that within precolonial Nigeria 'traditional rulers 'held tremendous power and exercised considerable influence. Alagoa (1985:77) notes that different political cultures created their own institutions in pre-colonial Nigeria. He posits that popular tradition presents the House heads or chiefs of the delta-city states as virtual despots and the amanyanabo or kings as responsible and careful about the general welfare of the people.

Lawal (1989:70) while lending credence to the view that in pre-colonial Nigeria, traditional rulers were veritable custodians that deemed their executive, legislative and judicial fructuous from tradition cited the work of Igbafe, P.A The Role of Traditional Rulers in Local Government on the Benin Oba where he observes that The socio-political organization of Benin during the pre-colonial years of its history was dominated by the special position occupied by the Oba, who was the pivot around which everything revolved: the supreme, religious as well as the civil authority in the land. This special position of the Oba found expression in the physical separation of his settlement or palace (eguse Oba) and those dependent on him or connected to him by specialties from the rest of the town and people. The Oba was by tradition the fountain of honour and the giver of tittles, his position being surrounded by an aura of sacrosanctity on account of his priestly functions and as a representative of the long line of ancestors who had held the reins of power over the land before him.

Ehindero (2006:37) similarly observed that traditional rulers epitomized local administration before colonial administration was introduced into Nigeria and performed many of the functions of the modern Head of state before the advent of the Europeans'. In the same vein, the Ogbah people of Northern Niger Delta saw their Oba 
or EzeOgbah as the embodiment of ancestral traditions before the advent of colonialism in about 1902 AD. Alogoa (1985:79) demonstrates that in some political organizations in the old Eastern Region, some age grade groups combined with titled personnel in the rulership of their domains as was witnessed among the Asaba and Aguleri. The Urhobo, Itshekiri, Ikwere, Ekpeye, etc. had their peculiar experiences.

The intrusion of colonialism dismantled the structures of traditional absolutism in virtually all the indigenous ethnic nationalities of the South-South zone in the Niger Delta. The use of gunboat diplomacy and brute force, cowered these paramount rulers into submission in the face of a more sophisticated weaponry and tactics of the West.

Under Lord Lugard, the British colonialists pursued a system of indirect rule more effectively from 1914 when the Southern and North Protectorates were amalgamated. Ashini (2010:127) defines indirect rule as a British system of administrating or ruling over her colonies with the use of local chiefs or appointed intermediaries using traditional laws and customs with British officials merely supervising the administration. Put differently, indirect rule system meant ruling the native African people through their own native traditional authorities. Thus, either the chief or as the chief-in-council was under the system known as the Native Authority which was vested with enormous power to act on behalf of the colonial government. Afigbo (1972:1) notes that, Indirect Rule or Native Administration was introduced to South-South central Nigeria before the imposition of direct taxation in 1928.This era according to Sasime (2000) necessitated the loss of their sovereignty of traditional rules even though their usefulness was still recognized.

It is common knowledge that the practice of indirect rule met resounding success in the North that had an enduring structure of central administration under the sultanate and emirate councils. In the West, mainly dominated by the Yorubas, indirect rule system was greeted with appreciable success as the Alafin and Obas had practiced centralized administration prior to advent of colonial rule. In the entire Eastern states that then accommodated the South-South zone the principle and practice of Indirect Rule left much to be desired. The British colonial administrators were forced to create an artificial institution to address the need for grassroot government Crowther and Ikime (1970: xi) observe 'before the colonial period, chiefs derived their authority or the power to rule from a wide variety of sources whether right of conquest or membership of a particular ruling family, primogeniture, etc. but in every case their source of authority was an indigenous African one. Under colonial rule, whether they had fulfilled all the traditional prerequisites for assumption of office, which would have allowed them to rule in pre-colonial times, their right to rule depended on the colonial authorities. One of the adverse consequences of the warrant chief process was the outbreak of the Aba Women Riot in 1929 with adverse consequences.

It is worrisome to note that at independence in 1960, the status of traditional rulers in Nigeria has not changed significantly. To sum up their beleaguered state, Jaja (2008) notes, 'today, traditional rulers, their institution, system and leadership are treated like outcasts in a democratic system. They are not mentioned in the Nigerian constitution of 1999; they have no compelling power or authority over their "sons" or the ability to help check and call them to order. As they are now constituted traditional rulers have no power or authority to act or help to check crimes or crises'.

\section{The evolution of local government}

The emergence of modern local government structure in the political history of the South-South could be traced to the colonial period. Obi (2010:37) notes that the colonial local government system was known as the Native Administration system or simply Native Authority.Orewa and Adewumi (1983) observe that the colonial native authorities were established progressively in their rudimentary forms from the 1890 s to the 1930s; they represented a system of indirect rule which sought to establish a form of local administration through traditional authorities. Harry (2010:68) notes that the Native Authority was mainly concerned with the maintenance of law and order for the smooth operation of the colonial government with other assignment such as the formulation of a uniform local government and this was possibly the raison d'tre for the appointment of warrant chiefs in the north, to conserve the traditional culture of the respective ethnic groups and to bring political administration nearer to the governed. Sir Clande Mac-Donald, Ralph Moir and Walter Egerton played significant roles in this period, Bassey (2006:59)

Another phase witnessed the establishment of modern local government authorities between 1950-1955 characterized by elections along British parliamentary model in Lagos and the former Eastern and Western Regions. Orewa and Adewuni (1983: xii) observe that although traditional members constituted a maximum of $25 \%$ of the most of the councils in the then Western Region and Lagos, The emergence of members elected on a political party basis showed the traditional rulers the green light to gradually withdraw from active participation in local government in these parts of the country. These elected local authority members were given a level of financial autonomy which also extended to personal and general administration issues.

The Native Authority system of the 1930s was succeeded by the Best-Man system of 1945-1950 which came into effect at the cessation of Second World War in 1945. Under this policy, each community was directed 
to send to the native authority councils and clan courts, a man it considered best qualified to represent its interest either a traditional chief or any kind of persons that had the confidence of the community for quality representation. This reform did not endure the test of time as pressure was mounted by popular based parties such as the NCNC, the Action Group, Village and Town Unions like Ibibio State Union, educated Nigerians mainly of Ibibio stock for more reforms which made the colonial administration to introduce an improved version of local government administration, Bassey (2006:66). There was also the county council system of 1951-1966 aimed at eradicating administrative bottlenecks of local government and also to entrench power in autonomous councils without overbearing control from District Officers. This was followed by the development and divisional administrative system of January, 1967-1975 as a consequence of the military coup of January, 1966 and the creation of twelve states in 1967 in which the states were at liberty to setup their own structure culminating in the South-Eastern and Mid-Western states introducing development administration system while the East Central adopted divisional administration. Between 1979 there was the cabinet or parliamentary system of the Murtala Muhammed and Obasanjo military regime which incorporated local government as the third-tier of federal governance and which was embedded in the 1979 constitution.

On the 1976 local government reforms Orluwene (2007:61) observes that they marked a watershed in the political history of Nigeria in that they birthed a uniform, single-tier system of local government the local government received a fixed portion of federal revenues.It is interesting to note that the features of the 1976 reforms have been preserved over the years. Other phases included the caretaker committee and sole administrator system of 1979-1983, of the Shagari administration the management committee system (19831985) of the Buhari/Idiagbon regime, the presidential system of 1985-1993 under General Ibrahim Babangida which was aimed at professionalizing the Civil Service. Then the cabinet system of 1993-1999 under General Sanni Abacha and the presidential system which came into effect since 1999.

\section{The development question vis-à-vis traditional rulership and local governance}

It is a truism that the sole aim of local governance is for grassroot development but the question remains 'how far has this objective been realized? Today, there are seven hundred and seventy four (774) Local Government Areas (L.G.As) in Nigeria. On a balance sheet, one can safely argue that the towns and cities housing the headquarters of these L.G.As have received some form of face-lift in the area of infrastructural development. In the South-South, a visit to L.G.A headquarters lends some credence to this claim. The same argument goes for state headquarters where rural towns become urbanized with trappings of a mega-city. Still on a positive note the 774 L.G.As have created jobs and contributed meaningfully in the area of capacity building. Closely allied to these is the issue of rural development which Ekpe (2006:128) highlights the major components to include

(i) Eradication of illiteracy through functional education

(ii) Boosting of food production through agriculture,

(iii) Community development through provision of basic amenities,

(iv) Rural transformation through water supply, housing, health centers, electricity and provision of rural infrastructure

(v) Diversification of the economy through integrated rural development and

(vi) The provision of equal opportunities to all through democratization process.

In the pursuit of rural development, various goals have been achieved in the banking sector such as the setting up of the people's Bank in 1992 under the chairmanship of Late Tai Solarin during the Babangida regime, the establishment of the Directorate for Foods, Roads and Rural Infrastructure, DFFRI and the setting up of mushroom micro-credit banks dotting many rural cities.

On a balance sheet, it is disheartening that most Local Government Areas have not performed creditably as a result of the "Nigerian factor". Majority of Local Government Chairmen see public office as a conduit pipe for looting the national treasury at the expense of the masses they swore to serve. In this regard Uya (2012:605) notes 'though Nigeria has experimented with various models of local administration since the 1950s, including sole native authority; federal native authority, local government authority, district and local councils, development administration, and since 1976, the all-purpose single-tier local government, there is a frightening consensus among all concerned, that local governments have failed, especially as props for peoplecentered democracy. Indeed, it has been forcefully argued that no Nigerian institution has been in greater need for review, reform, reorganization and revitalization than the local government system'.

As critical assessment undertaken by Tamuno (2012: 171) reveals that local governance has failed in the provision of social defense; and he goes further to decry their level of non-performance even where the emoluments of an elected councilor who has the equivalent of a school certificate and is just out of school are higher than those of a Professor in the university or a Judge of the High Court of a State'. Yet both entitlements come from the federation account. It is against this background that the call for local government autonomy 
needs to be taken with caution. The question is 'is it autonomy meant for unfettered lootings, and enthronement of endemic corruption?

On traditional rulership, the fact that the 1999 constitution is silent on its function begs the question. It is an obvious fact that two captains cannot steer one boat. Even at that, there are some functions like grassroot mobilization and sensitization that could be left solely for traditional rulers.

More so, traditional rulership from their knowledge of hindsight could play advisory roles to government functionaries of all categories right from the presidency to the least councilor. It will be worthwhile if a traditional ruler of the status of the Amanyanabo of Twon Brass, Navy Captain Diette Spiff (Rtd) is statutorily appointed to function as a Special Adviser either at the State or Federal level.

\section{Suggestions and recommendation:}

For the dividends of democracy to trickle down the grassroots, both the fabrics of traditional rulership and local governance should be strengthened. Local governance, it must be understood, extends to local government administration.

It needs reiterated that there is the need for a review of the 1999 constitution with the aim of enshrining, in no uncertain terms, the statutory functions of traditional authority as is the case in South Africa, Ashiru (2010: 135).

Their remuneration should be clearly spelt out in addition to whatever support they might receive from their subjects. In addition, where they belong to an oil bearing community, the Constitution should provide that, the multinational companies operating in such an area should allocate a percentage of the royalty to them. The traditional rulers should endeavour to be non-partisan in their dealings. They are seen as fathers to all and shun fanning the embers of disunity in any guise.

Instead of angling for local government autonomy, this paper suggests that the officials in the system, ranging from the LGA chairman to the councilors, and their principal officers should demonstrate prudence, probity and accountability in managing public treasury. A situation where most LGA chairmen just manage to pay salaries and disappear into the thin air is condemnable.

Most local government roads are debt traps with public utilities grossly inadequate in the provision of pipe borne water, electricity and quality education cum security of lives and property. Odoh \& Abubakar (2012: 33) advocate for team work in facilitating local government delivery at grassroot level.

\section{Conclusion:}

The problems and prospects of traditional rulership and local governance have been examined in this paper from a historical perspective. Tracing the genesis of traditional institution has revealed the negative impact of colonialism that dismantled their structure through forceful subjugation leading to what Sasime (2000) describes as 'rulers without sovereignty'. Prior to the colonial conquest, traditional rulers were seen as paramount in every sense of the word in the governance of their subjects. They even combined priestly functions and more often served as the custodian of primordial customs.

The evolution of local government administration passed through epochal stages ranging from the Native Court system of 1891-1912, the sole Native Authority or the Lugardian system (1912-1919, the BestMen system of 1945-1950 to the cabinet system of 1993-1999).

While the functions of the local government are clearly spelt out in the 1999 constitution of the Federal Republic of Nigeria, no role was assigned to the traditional rulership. It has become crystal clear that colonialism was responsible for the rise of local government authority and at the same time, the demise of traditional institutions.

The issue of grassroot development was equally addressed. There is much to indicate that the Local Government Areas (L.G.As) are paying lip service to the holistic development of their constituencies. The "Nigerian factor", which is a euphemism for corruption and ineptitude, has been identified as being largely responsible for this phenomenon. It is hoped that if the suggestions outlined in this paper are adhered to, the entire system will witness a sustainable transformation. 


\section{References}

[1]. Afigbo A.E. (1972) The Warrant Chiefs, Indirect rule in South-eastern Nigeria, 1891-1929

[2]. Alagoa, E.J (1985) Nineteen century Political Culture in the Eastern States of Nigera, Ade, Ajayi, J.F. and Ikare, B. (ed.) Evolution of Political Culture in Nigeria, Ibadan: University Press Ltd.

[3]. Agbese, P.O (2004) Chiefs, Constitutions and Policies in Nigeria, West African Review, Issue 6 http//www.chr.up.ac.za/chr

[4]. Ashiru, D. (2010) Chieftaincy institution and grassroots development in Nigeria, Babawale, T. Alao. A, and Adesoji, B. (eds.) The Chieftaincy Institution in Nigeria, Lagos: Center for Black and African Arts and Civilization (CBAAC).

[5]. Assibong, P and Akpan, D (2006) Theproblems and challenges of local government administration in Nigeria. Akpan-Umana, O.E, Oborgu, F. U and Gofwen R.I (eds.) Politics and grassroots administration in Nigeria, Issues, Challenges and prospects, Uyo: Diamond Ville Digita and Publishers.

[6]. Awofeso, O. (2006) Forms and Dimensions of grassroot administration in Nigeria, Akpan-Umana, Oborgu, F.U and Gofiven.R.I (eds.)Politics and grassroots administration in Nigeria.Issues, Challenges and Prospects.

[7]. Bassey, J.R (2006) Theevolution of local government system in Nigeria, from the pre-colonial period to the present, Akpan-Umana, O.E, Oborgu, F.U and Gofwen, R.I. (eds.) Political and grassroot administration in Nigeria, issues, Challenges and prospects, Uyo: Diamond Ville Digital and Publishing.

[8]. Crowther, M. and Ikine, O. (1970) West African Chiefs, Their Changing Status under Colonial rule and independence, Ife: University of Ife, Press

[9]. Dike, K.O (1956) Trade and Politics in the Niger Delta.London Clarendon Press

[10]. Ehindero, T.J (2006) Traditional rulership in Contemporary political setting and theparadox of its existence in Nigeria,Nigerian Heritage:Journal of the National Commission for Museums and Monuments Vol. 15.

[11]. Ekpe, A. (2006) Local government and grassroot development in Nigera: problems and prospects, Akpan-Umana, O.E, Oborgu, F.U and Gofwen, R.I (eds.) Politics and grassroots administration in Nigeria: Issues, Challenges and Prospects

[12]. Emordi, E.C and Osiki, O.M (2010) Traditional rulers under military rule in Nigeria, 1966- 1999 Babawale, T. and Adesoji, B. (eds.) The chieftaincy institution in Nigeria, Lagos: Centre for Black and African Arts and Civilization (CBAAC).

[13]. Fasehun, M.A (2010) Therole of traditional rulers in the celebration of Ogun festivals in Ondo kingdom, Babawale, T, Alao, A and Adesoji, B. (eds.) The Chieftaincy Institution in Nigeria Lagos: Center for Black and African Arts and Civilization (CBAAC)

[14]. Harry, D.M (2010) Dynamics of grassroot governance in Nigeria, Port Harcourt: RohiPrinting and Integrated service.

[15]. Jaja, S.O (2008) The collapse and ultimate survival of traditional rulers, traditional system and leadership in the Niger Delta since Nigeria's independence (1960), Derefaka, A.A and Okorobia, A.M (eds.) The Future of the Niger Delta: the search for a relevant narrative, Port Harcourt: Onyoma Research Publications.

[16]. Lawal, N.A (1989) the position of the chiefs, Usman,Y.B (ed) Nigeria since independence, the first 25 years Vol.1. The Society, Ibadan: Henamann Educational Books (Nig) Ltd.

[17]. Obi, E. A. (2010) Local government administration in Nigeria, Obi, E. A (ed.) Comparative local government, an ecological approach,Orutihe: Bookpoint Educational Ltd.

[18]. Oborgu, F. (2006) The imperatives of local government administration in Nigeria.

[19]. Odoh, A. and Abubakar, U. (2012) Leadership and Team building for effective service delivery at the local government levelFederal Republic of Nigeria National Workshop for Local Government Key Functionaries on Repositioning the Local Government for effective service delivery in Nigeria, sponsord by forum of Chairmen of Local Government Service Commission and facilitated by Departments of Local Government Studies of Ahmadu Bello University, Zariah; Univesity of Nigeria, Nsukka and ObafemiAwolowo University, Ile-Ife.

[20]. Okara, O .C. (2009) Local government Councils and individuals for urban and rural developmentPort Harcourt: Prelyn Fortunes Ltd.

[21]. Orewa, G.O and Adewunmi, J.B (1983) Local government in Nigeria, Benin City: Ethiope Publishing Corporation.

[22]. Roberts, F.O.N (2004) Traditional rulers, governance and the post-colonial state, Vaughan, O. (ed.) Indigenous political Structures and governance in Nigeria, Ibadan: Bookcraft Ltd.

[23]. Uya, O.E (2012) Local government as the cornerstone of people centered democracy, Imbua, D., Akpan, O., Amadi, I. and Ochefu, Y., (eds.) History, culture, diasporas and nation building, The collected works of Okon Edet Uya, Bethsda: Arbi Press.

[24]. Sasime, I. (2000) Rulers Without Sovereignty, the Chieftaincy Institution in Nigeria, Port Harcourt: Outreach Publications. 